\title{
SCHOOL, CULTURE \& MOVEMENT: SUBJECTS/ACTORS FACE THE TRACES OF THEIR OWN ACTIVITY WHEN CREATING ALBUMS
}

\author{
N. PAIRIS \\ Montpellier University (France) \\ nadinepairis@aol.com
}

Article received in November/2014 and accepted in April/2015

DOI: 10.15628/holos.2015.2561

\section{ABSTRACT}

This article concerns pupils' activity operated from the theoretical and methodological framework of data analysis of the "process of action" (Theureau, 2004) supporting on activity tracks (what emerges from the pre-reflexive consciousness) and video recordings proceeded with individual interviews questioning the actors about their work : creation of albums into two classes of cycle 2 (one of them is an experimental artistic and cultural educational classroom) with the help of an author/illustrator. The understanding of pupil's activity answers the hypothesis of getting to work with creativity (Vygotski, 1930) in studying the "school well-being", the discourse analysis (case of Ramone who, in 2013, is not involved in the album creation while in 2014 he does not
\end{abstract}

want to go out for a break before having finished the activity of visual art) as well as the posture of their bodies at a moment of attentive listening. The results reveal that pupils need more movement than being in stand by (Jorro, 2013; Dewey 1934), in exploring their relationship to the space children become aware of the other ones (action vs passivity). The analysis of the pupils' activity puts into perspective the impact of the artistic and cultural practices on learnings and movement (performance of their musical tale -moving in space with big-sized illustrations-, graphic movement : not only in writing but in positioning their body to accustom them to feel it before it hurts them) as means of expression and cultural fact.

KEYWORDS: Process of action, creativity, artistic and cultural education, posture of bodies, activity tracks

\section{ESCOLA, CULTURA E MOVIMENTO: ASSUNTOS/ATORES ENFRENTAM OS TRAÇOS DE SUA PRÓPRIA ATIVIDADE QUANDO CRIAM ÁLBUNS}

\begin{abstract}
RESUMO
Este artigo centra-se na atividade que os alunos realizaram a partir do referencial teórico-metodológico de análise de dados da "curso da ação" (Theureau, 2004), com base em registros de atividade (o que emerge da consciência prerreflexiva) e de gravações de vídeo acompanhadas de entrevistas que interrogam os atores sobre o seu trabalho: a criação de álbuns por duas classes de ciclo 2 (dentre elas, uma é classe experimental de educação artística e cultural) com um autor/ilustrador. A compreensão da atividade do aluno responde à hipótese do pôr-se a trabalho pela criatividade (Vygotsky, 1930), estudando o "bem-estar escolar" obtido, a análise do discurso (o caso de Raimundo que, em 2013, não se dedicou à criação do álbum, mas que em 2014 não quer ir ao recreio sem
\end{abstract}

haver terminado a atividade de arte visual), bem como a postura de seus corpos no momento da escuta atenta. Os resultados indicam que os alunos têm mais necessidades de estar em movimento de que ser passivos (Jorro, 2013; Dewey 1934). Explorando sua relação com o espaço, as crianças tornam-se conscientes dos outros (ação versus passividade). A análise da atividade dos estudantes põe em perspectiva o impacto das práticas artísticas e culturais sobre a aprendizagem, bem como o impacto do movimento (interpretação de seu conto musical: deslocamentos no espaço com ilustrações de grande formato; gesto gráfico: não só a escrita, mas o posicionamento do corpo para acostumálos à sensação antes de machucá-lo) como um meio de expressão e como fato cultural.

PALAVRAS-CHAVE: Curso da ação, criatividade, educação artística e cultural, postura do corpo, registro de atividade 


\section{INTRODUCTION}

"In a school in the south of France, pupils wrote their own albums ...." They were involved in a cultural creative school project. It began in 2013 and will finish in 2016. They created albums in the context of pupils getting to work at school. Results showed that their involvement into action created a favorable working environment and gave them a welfare not only at school (bridging the gap between learnings and creativity) but in their family life. In fact, pupils used their album as "intermediary" between them and their families as "childhood security blanket" taking comfort in their everyday life.

Our research justifies in addressing the issue in the current context of school improvement for the 21st century through education and creativity (Peillon, 4/19/2013), it is about priority education as a ground for innovation for Educational Success. This is also part of equal rights for all (Law 2005) and inclusive education for pupils with special needs.

This article focuses on a mediation in children's literature in an experimental class of arts and cultural education developed as a tool for school mobilization. We studied pupils from 7 to 9 years old in a school of a difficult district. We thus could better understand the contribution of visual arts during the construction of their albums (Dewey, 2005). We were able to identify how pupils involved in reading and drawing activities as well as their perceptions of their practices. Our theoretical and methodological framework for analysis of data from the "process of action" (Theureau, 2004) is based on activity tracks (what is emerging from the pre-reflexive consciousness). This analysis of a praxis of acting pupils is turned into a police novel "New neighbors" and a musical tale "Sabrina's adventure".

This plan of action allowed the transversality of activities about reading and writing workshops with an author illustrator showing his children's books in order to explain the involvement of each pupil in the mediation process. We noticed that the latter was able to increase their motivational strategy with creativity and that transfers exist between learnings and artistic practices. There was an educational effect given by the "school welfare" gladness, empathy, enthusiasm, gratitude, motivation and involvement also seen in internships of Excellence (Jorro, 2013, p.34).

The objectives of our mediation is to allow school drop-outs pupils to get to work at school and to implement the question of the meaning given to learnings (Perrenoud, 1994). The class group has indeed been able to give meaning to work in interaction during writing, reading and illustration workshops. They shared their production allowing so the overcoming of significant personal barriers in creating a true partnership without any fear of being judged.

Pupils showed that they needed "more movement than being in stand by" at school (Jorro, 2013). CHA was interviewed and said "in writing a book that helped me to better read and write." She got a largest mobilization on her learnings.

\section{UNDERSTANDING PUPILS' ACTIVITY}

It addresses hypothesis allowing pupils to get to work with creativity (Vygotsky, 1930) in studying "school welfare" (discourse analysis) case of Raimundo who, in 2013, was not involved 
in the album creation, whereas in 2014 he did not want to go out in the playground, for a break, before having finished the activity of visual art, as well as the posture of their bodies when they were closely listening.

Results indicate that pupils needed to be more in movement than passives (Jorro, 2013; Dewey 1934), exploring their relationship to space children became aware of the other ones (Action vs. passivity).

Our article focuses on strategies to get "meaning" by learning (language activities "in groups" Meirieu 2010 and visual art practices) and the co-construction of the appetite for reading. Our research action (artistic and cultural mediation as a tool for mobilization and fighting against school drop-outs pupils) informs the analysis of pupils' activity, thereby putting into perspective the impact of artistic and cultural practices on learning and movement as means of expression and cultural fact. It tracks the most common categories of activities.

\section{PARTICIPATORY ACTION RESEARCH METHODOLOGY}

This research was conducted using the participatory action research with selfconfrontation interviews described by Theureau (2004). This methodological approach tries to understand the subjective experience of the subject. We were thus able to follow pupils facing the tracks of their own activities during the creation of their albums.

We decided to explore different forms of observations through videos and guided interviews with questions in reactivating amnesic tracks.

"Understanding the action is connected to an embodied meaning which precedes intellection" (Merleau-Ponty, 1942)., LIN "emotional identification with the character : Sabrina."

The discourse of the subject/actor facing the tracks of his activity becomes the subject/spectator of his own experience. The process of action then allows to immerse and look in the thickness and time of the alive subject in order to better understand what is lived in the experience. Through this process pupils thereby permitting to give us what they felt during their experience of these creative cultural projects.

By focusing on the experience of the actors, the process of action method can define knowledge as "a particular aspect of the experience," "the experience of actors at any time." In describing the history of the located pupils' experience, it allows us to assess finely knowledge on which the actions of learners are based and thus leads us to describe the history, the dynamics of the pre-reflective consciousness.

To realize our ethnographic and longitudinal study, we conducted a cohort study of a class. This School Project is an experimental cultural and artistic class.

As part of this exploratory research, we filmed the sessions while creating the album in 2013 and 2014. In order to analyze the activity we performed the cutting sequences on recording actions of the actors in interaction, then we made sessions of self-confrontation. We finally conducted an interview with the author illustrator and with the teacher on the pupils' activity analysis during this artistic mediation. Then we analyzed the data (Blanchet, Gotman, 2007). 
"The vitality of action results from the subject's ability to give meaning to action, to discover new goals in the identification of new opportunities" (Clot, 2010). Also with the approach developed by Ricoeur $(1991,2004)$ we can establish links on the issue of action and use it in the context of our research on pupils' engagement.

According to the theory of the capable man, Ricoeur assigns a major role in acting subject understood not as a simple movement but the actor who can attest to his actions.

"The involvement is based on a conception of educational success including the pupil as a person, pointing to the importance of the construction of autonomy. "

Epistemic student ready to fight with the world of knowledge gives way to the student whose academic experience opens cultural dimensions. Educational success then depends on the recognition of this singular student. "(Jorro, 2013, p. 43).

"The desire for action also means the possibility to identify effects of intervention with students. If the notion of efficiency is not direct, it is nevertheless present as soon as the educational support is designed in terms of progression that pupils must get". (Jorro, 2013, p.49).

School must provide new learning for children. The way for this learning is linked to the ability of the teacher, his investment and his ability to implement the conditions of autonomy (groups, written productions workshops), creativity and cooperation between his students. Thanks to the climate of cooperation among pupils it will encourage a peaceful relationship with the authority and promote basic skills (CHAY : using books in order to better write, read and concentrate) and will help to learn to live harmoniously together (enhance their self-esteem, collective intelligence, creativity).

We believe that the link between student work and activity analysis could clarify the practices of reflexive creativity thanks to the fact that students were able to make a return on their own practice. So that students will remobilize and mobilize their knowledge through artistic contribution, we performed the same way for the second artistic mediation by supplementing a "Book of Cultural works".

The album as a project with a finalized product had a huge impact and helped to bring learning and creativity together for a new approach in the context of human aesthetics movement thanks to visual and graphic arts. We notice that there may be a possibility of mediation to motivate pupils to improve their relationships with school by mobilizing their creativity to build their own learning tool.

We put forward the idea that the development of these albums helped to create a kind of questioning so that students "come into reading" in the construction of the story of their album to restore "continuity between this refined and intense experience that works of art and actions are ... and daily events universally recognized as elements of experience" (Dewey, 2005)

\section{REMOBILIZATION ON WORK AND ACADEMIC SUCCESS}

The issue is to know if we can help remobilization on work and pupils' academic success with special educational needs, using creativity through action and movement with visual arts in the context of an artistic and cultural mediation? 
Creativity work (Vygotsky, 1930) through an educational, artistic and cultural mediation are essential skills and important elements to ensure academic success. It would thus help educational practices to progress and access rights statutes of 2005 \& 2013.

The project of writing the children's book aimed to put to work pupils in the same class group, motivated by the guide as part of a pilot class and strengthen the personal project of student (Perrenoud, 2002), the project approach (Savoie-Zajc \& Lanaris, 2010).

There was a real pupils' engagement in the process of creating albums. "The power to act in Ricoeur derives not only from the effectuation of the action but also how subjects report and certify"(Jorro, 2013, p.43). There was also a student autonomy in their work and in their thinking and improved report for school tasks. It is to use art in the center of the project as a way to fight against academic difficulties and illiteracy. There must be a change within the school and not only in new schools (Meirieu, 2004). It is therefore to assist teams in change. "The implication is based on a conception of educational success including pupils as a person. Pointing to the importance of the construction of autonomy, teachers use the term development to enhance the relationship between the dimension of knowledge and the knowledge to be."(Jorro, 2013, p.36).

Interview with the teacher: "They were all willing to help, as soon as they finished something they spontaneously wanted to help other ones, asking me : Can I help someone? » "DEN illiterate child tried to decrypt an album to make sense to the story presented by the author illustrator. This mediation facilitated the access to imagination. Interview with the teacher : "They all were in action on a common project but they all were doing something different, which is very few and far between. They all knew in what direction we were going to and it worked perfectly well».

Creativity allowed to find new experts where we did not expect to: "Expert thanks to creativity" JIM (drop-out pupil) recognized expert "you're too strong" by his peers when he drew buildings in the first album : recognition.

Interview with the teacher: "His friends agreed he could do something beautiful and finalized. He was "expert" and It made him feel good"

- Tutoring : legitimacy found by some students: MAR helped DEN writing the text of the police novel, she still did not know how to read after three years spent at school (the objective of the Artistic and Cultural Education multigrade class is to teach her how to read the next two years).

- Interaction groups : Cooperation.

The objectives of our research could be validated. There was a production of meaning that undoubtedly affected the motivational strategy for all but especially for those in underachievement or illiteracy because they could benefit of a student tutor, a position he was able to quickly reinvest to explain lessons

\section{RAIMUNDO}

\subsection{Academic situation}

He was performing poorly at school. He had a lot of difficulties. 


\subsubsection{June 2013}

At the end of the year we had to admit that Raimundo wasn't interested by the artistic and cultural mediation. What were we going to do next year so that we could get him interested in the second album project ? When he was interviewed, he said "I'd like to know how to read", school seemed not to be uppermost in his mind.

\subsection{2 $2014: 1$ st semester}

There were first of all writing workshops where he struggled to express his ideas. The second year of arts and cultural education project was, in fact, to write a musical tale that had then to be staged by students

\subsection{3 $2014:$ 2nd semester}

Then, from February to June, there were visual art workshops.

When the author illustrator came in class he hurried to finish the visual art work to show his dragon to the teacher while the previous year he was playing with his pencils and was noisy because he was not interested at all by the activity.

There were several sessions of visual art workshops. The drawings were made on bigsized cardboards in order to create settings and illustrations for their new album "Sabrina's adventure."

He was therefore more invested in the creation of the latter.It was in this context that Raimundo was able to demonstrate greater creativity in using space allowing him to cooperate with peers to set color illustrations. When the bell rang, the other ones went out for a break but he did not want to. During interviews, he answered the question "did not you like to go outside ?", he replied:" Yes I did, but I prefered to stay and finish what I was coloring !". "I was not out in the playground because I had to finish my illustrations. This was for the book, everyone would see it. This was extremely important that we got this done and got it right".

We gave him responsibilities in a second sequence of visual arts, so that the group could operate quietly, we named him group leader. A that point he took his role very seriously. As he was often not integrated among his peers, when he was drawing on the ground, he invested space with large movements and was so at the center of the group. In addition, this activity gave him a freedom of movement in space closer to his peers. In the sessions of self-confrontation, he explained that "it was a good thing to work with a lot of space and turn around the drawing because it established links with the other ones".

Interview with the author illustrator: "In the plastic language, it's not just writing, it is the body that will create a movement that will leave tracks".

Pupils were respectful of each other and did not encroach on their respective areas of work. 


\subsection{Discussion}

Students need to be more in movement than in stand by (Jorro, 2013; Dewey 1934), exploring their relationship to space, children were conscious of the other ones (Action vs. passivity).

The musical tale allowed more movement, pupils say that "it was good for them to work on large formats and create settings to illustrate their tale during the performance of their play."

After the presentation of the album in September 2014, interviews showed the strong pupils' mobilization through the impact of this new form of activity that is to say the artistic and cultural creativity. They found important to be moving and not sitting at their desk (Action vs. passivity). When they finished the prescribed tasks they lost no time in operating the computer to type the copy of their writing workshop.

Since, he used to have responsibilities and adults concerns, this work of movement with visual arts placed him in his child's position inside a fantasy world and also allowed to create links between creativity and learning because it was by the graphic movement that he managed to connect with the fundamental learning. Indeed, Raimundo revealed in his interview that creating an album "it was good, it helped me a little to read."

Accompanying the group by the researcher was an opportunity to visit a "specified lived experience." In this interview, he told us that "this experience was important, that the points of reference among peers was favorable to him". We can infer that the body, emotional, cultural and social receptacle was a mediator in the class when he worked in visual art workshops and allowed him to build relationships with his peers.

\section{RESULTS}

\subsection{Bodies posture in attentively listening}

Also, the study noticed that many students had the same posture when they were attentively listening. This phenomenon had been observed in two different schools with two classes.

The pupils' behavior during illustration album sessions drawn our attention. Their bodies posture was the same with pupils who did not know each other. We might think, at first glance, they were tired because they hold their head with an elbow, but on closer look they were totally immersed in the fantasy world that introduced them the author illustrator. They explained it so, INE "in my head I started to see the character moving and then I could imagine that it was as if I were the character and he was alive."

\subsubsection{Visual arts workshops results}

Visual art workshops facilitated the observation of pupils' relationships among each other. Space and free movements of their bodies around large format settings allowed them to learn in a different way. They kept in mind "action, mutual help, cooperation, kindness and pleasure thanks to their albums". They were able to gain autonomy of thought and action and were motivated and self-disciplined them, in interview WYS said "usually RIH was not careful, so I told 
him that he had to do it right because it was for our book. "Other students also expressed the same feeling "we had to finish our drawings, it was important, they had to be well done because it was for our book!".

For over two years they were used to working creativity and gained autonomy of thought and action. In sessions of self-confrontation, they had a feed-back on their own practice and on their activity reflecting the contribution of creativity in learning.

Interview of the teacher "when replacing the permanent teacher the new one was surprised to notice that pupils wanted to make writing workshops. "Please, could you give us the beginning of a sentence ? ..."

LIN "Our book was like a dictionary we could find words that we did not know." It is a sign language in order to better learn to write through graphic movements, RIH "since I had a beautiful writing, it helped me to better write words." YAS "With the book that made it easier to read, I read the book several times and learned it by heart," he recited then the beginning of his tale.

Movement helped them, this is undeniable: "More freedom through space. More understanding, cohesive group. They did not want to go out for a break. " Author and illustrator's identification for the first album and identification with characters for the second one.

They relived situations of "happiness" that they felt when creating oversized illustrations allowing characters identification. There was the concept of sharing, respect, acceptance, LIN said "INE had not many friends but in creating 2 albums, she found herself better integrated, she brought books to school and we read them together in the schoolyard."

\subsection{Unexpected results}

According to self-confrontation interviews we found that pupils could express their ability to write albums in order to link with their multimedia marks. It allowed to create links between students, video games and / or series characters on television. Pupils were transposed into action by becoming identified with characters.

They explained that "the first illustrated album with small-sized drawings did not allow them the same identification as those created in big size in their story."

There was maybe a kind of identification with what they can see on television programs with a transposition of the story of their album to the characters of well-known series, "INE : The character called V... do you know on which channel it is ? "They made connections with TV shows:" We will be famous, a star".

Transposition may have occurred through the identification with oversized characters. They identified with their characters, girls with Sabrina and boys with Prince François and explained that "it seemed to them to be as in a video game, characters were bigger than us! "(YAS, MOH), they had the impression to live the action with him, they flew to find Sabrina's cat. Other pupils "were living the story" by learning by heart "to replay it."

They lived their adventures as if they were the ones who had this magic life and that made them "happy." They had like glitters sparkling in their eyes... 
Drawing on the ground enabled them to acquire a spatial notion that they did not know before.

This allowed them to better understand adults' emotions (friends, parents). They even sometimes "wanted to cry".

Girls who identified with Sabrina : LIN "it was so real, how she was, that I felt actually her emotions and it helped me to feel what adults could feel." INE "She was as tall as me, it was as if, in my head, I saw her for good and after she moved, I could made her alive"*

Unanimously the creation of these albums gave them the feeling to be different than before, "alive" and to have "grown up", "thanks to the book we could be famous, it made them feel better. For some pupils "it took away the sad events of their personal life." They import the profit of the book from school to home.

It is important to note that action, freedom of movement and expression was a source of life. Thanks to the characters they made alive, they felt themselves more alive too, LIN "Before I was sometimes sad and when I read my book, I felt right. I saw what was created and when we argued with girls, we could recall the memory of the characters' emotions so it helped us to better understand our friend's emotions, it was as when the heroine had got lost and was separated from her parents. "

Creativity, action and movement was for them a source of autonomy and they noticed that they had acquired of maturity, CHE "it was as if we were older and as if we made activities for adults".

They were very proud of their work and became identified with the author illustrator. They largely admired him. Some of them even expressed the wish to become a writer or an illustrator.

Space and large-sized drawings were for them a source of freedom, but also an additional work. Interviews : WYS "it was harder to work on large-sized drawings but with the group it became easier." CHE "we could work with a group of friends, we learnt things and at the same time we did not have the impression to work"; "Space, movement, that made us free."

"In a group it helped to know and respect each other. It gave confidence in us. "

Hypothesis allowing pupils to get down to work with creativity defined the emerging process of creating albums. It has been a vector allowing to situate pupils on their children's place by giving them access to the world of imagination and to assemble the data of experience to build a new reality to their needs.

Albums as a project (Savoie-Zajc \& Lanaris, 2010) with a finished product are bridging the gap between learnings and creativity giving an aesthetic dimension in education. After two years of artistic and cultural mediation children really got a school welfare.

Students were proud of their collective project which gave them perspectives. In 2015 they are going to work on a theater project with always the creation of an album as track of activity and creativity. 


\section{CONCLUSION}

The analysis of student activity during remediation by writing, publishing a book and working with an author illustrator with pupils from modest backgrounds puts into perspective the impact of emerging tools for learning such as artistic and cultural practices. We studied the behavior of pupils trying to clarify the reasons that made them act and thus understand what allowed them to adapt their relationship to other ones.

The graphic movement enabled some of them to write better, both in terms of text quality in the writing workshops and beauty of the movement, RIH "since I made big-sized drawings, I write better. It made me want to write. "

Thus graphic movement is not only useful for writing but also for the positioning of their body to get them used to feel it before it hurts them, as means of expression and cultural fact.

For Vygotsky (1934/1997) "It's by game or story, which are not simple reproductions of real-life impressions, but creative re-elaborations of these, that the child connects and assembles the data of experience to build a new reality, answering his curiosities and his needs. As far as imagination is built with materials taken from reality, the creative activity of imagination directly depends on the variety of experiences".

This creative cultural project was not only able to broadcast welfare and allow the mobilization on school work as well as pupils' academic success but it also allowed them to achieve an educational and aesthetic experience of the human movement.

\section{REFERENCES}

1. ARBORIO, A.M., FOURNIER, P. The survey and its methods: direct observation. Paris, Nathan, 2010.

2. BARBIER, R. Action Research. Paris, Anthropos, 1996.

3. CLOT, Y. Basic research in the field: a third way. Continuing Education, 177, 2008/4, 67-77, 2008.

4. DEWEY, J. Art as Experience. Farrago Editions, University of Pau, $1934-2005$.

5. JORRO, A. The professional commitment to education and training. Brussels, Boeck, 2013.

6. LANARIS,C., SAVOIE-ZAJC L. "The school teams project: many levels of collaboration." Work together in school-establishments and training. Brussels, De Boeck, 2010.

7. MEIRIEU, P. Pedagogies of groups. Learning Group - 1. Lyon, Social stories, 8th ed., 2010.

8. MERLEAU-PONTY, M. The structure of behavior. Paris, PUF, 1942.

9. PERRENOUD, P. Art student and a sense of school work. Paris, ESF, 1994.

10. PERRENOUD, in the teaching profession Ph. (2003) Developing reflective practice. ESF, 2003.

11. RICOEUR, P. A school of phenomenology. Paris, Vrin, 2004.

12. THEUREAU, J. Process of action "basic method". Toulouse, Octarès, 2004.

13. VYGOTSKY, L. S. Thought and language. Paris, La Dispute, 1934-1997. 
14. VYGOTSKY, L. S. Psychology of art. Paris, La Dispute, 1925-2005. 